BNL-67519

Informal Report

\title{
Building 830 Gamma Irradiation Facility Evaluation of Options for Its Future Disposition
}

Prepared by:

Biays Bowerman

Mel Cowgill

John Heiser

Paul Moskowitz

September 30, 1998

Environmental \& Waste Technology Center

Department of Advanced Technology

Brookhaven National Laboratory

Upton, New York

${ }^{*}$ This work was performed under the auspices of the U.S. Department of Energy 


\section{EXECUTIVE SUMMARY}

In the spring of 1997, the Suffolk County Department of Health Services identified the Building 830 Gamma Irradiation Facility (GIF) as an underground tank regulated under Suffolk County Health Code, Article 12. Subsequently, BNL initiated a project to review the GIF and to develop options for its future disposition.

The GIF, built in 1967, consists of a pool, $8 \mathrm{ft}$. by $10 \mathrm{ft}$. and $13 \mathrm{ft}$. deep, containing water and, at the bottom, 354 sealed cobalt-60 gamma sources. The water depth provides shielding from the gamma sources; total cobalt-60 inventory, as of September, 1998, is 29,000 Curies. Safety features focus primarily on maintaining the water level shielding the sources. An area radiation monitor alarms throughout Building 830 if radiation levels exceed $5 \mathrm{mrem} / \mathrm{hr}$, a situation that can occur if the water levels drop more than 5 feet. A refill system activated by a float is available if the water level drops 6 inches. The refill system operation is monitored through a water meter on the refill line, with readings being recorded weekly. Water levels are also measured and recorded weekly by a gauge mounted on the pool cover. Since readings have been recorded (1995), there has been no indication of the water level dropping or of the refill system operating. The refill system has a secondary shutoff activated by a float to prevent tank overflow. An emergency refill line, a 3-inch copper pipe has a connection for a fire hose at the back of the building. Finally, a security system of motion detectors, surveillance camera, and door sensors was installed in 1996.

For the past 5 years, there has been one regular user, GEC-Marconi, who irradiate advanced piezoelectric crystals as part of a manufacturing process. Income from this user amounts to about $\$ 25,000$ per year.

Suffolk County Health Code Article 12 imposes specific requirements on tanks containing hazardous materials, to minimize the potential for releasing these materials to the environment. The water in the GIF pool contains small amounts of radionuclides and hazardous constituents, namely cobalt-60, cesium-137, lead, and cadmium. Dissolved lead, from the corrosion of lead shielding in contact with water at the tops of the air sampling tubes, is the only constituent which exceeds levels allowed for drinking water and for release to sanitary sewer systems. The concentrations of cobalt-60 and cesium-137 are extremely low and well below drinking water standards.

Options for the future disposition of the GIF were developed after discussions with operators of other (non-BNL) irradiation facilities, source brokers and vendors, radwaste disposal vendors, and the BNL Waste Management Division. The options considered in this evaluation fall into five categories:

- $\quad$ Compliance with article 12 , retention of all sources, continued operation of the GIF;

- Removal and recycle of all sources, either directly to other facilities or indirectly via commercial enterprises;

- Partial disposal, retention of some sources on site, either in the GIF or in dry storage;

- $\quad$ Onsite dry storage of all sources; and

- Immediate and complete decommissioning, disposal of all sources. 
Cost estimates for these options were developed based on estimates from two vendors and on previous experiences with similar tasks carried out by BNL organizations. A comparison of the total costs involved for each option is as follows:

\section{Cost Estimates for Options Considered}

\begin{tabular}{|c|c|c|c|c|}
\hline \multirow[t]{2}{*}{ Option } & \multicolumn{3}{|c|}{ FY99 Costs } & \multirow{2}{*}{$\begin{array}{l}\text { FY03 } \\
\text { Costs* }\end{array}$} \\
\hline & Subcont. & $\mathrm{BNL}$ & Total & \\
\hline Compliance with Article 12 & --- & $\$ 20,000$ & $\$ 20,000$ & $\begin{array}{l}\$ 404,000 \\
\text { min. }\end{array}$ \\
\hline Source recycling & $\begin{array}{l}\$ 152,000 \\
\text { min. }\end{array}$ & $\$ 120,000$ & $\begin{array}{l}\$ 272,000 \\
\text { min. }\end{array}$ & --- \\
\hline $\begin{array}{l}\text { Partial disposal with onsite dry } \\
\text { storage }\end{array}$ & $\begin{array}{l}\$ 212,000 \\
\text { min. }\end{array}$ & $\begin{array}{l}\$ 120,000 \\
\min . * *\end{array}$ & $\begin{array}{l}\$ 332,000 \\
\text { min. }\end{array}$ & $\begin{array}{l}\$ 134,000 \\
\min .\end{array}$ \\
\hline $\begin{array}{l}\text { Partial disposal with continued } \\
\text { use of GIF }\end{array}$ & $\begin{array}{l}\$ 212,000 \\
\text { min. }\end{array}$ & $\$ 20,000$ & $\begin{array}{l}\$ 242,000 \\
\text { min. }\end{array}$ & $\begin{array}{l}\$ 282,000 \\
\text { min. }\end{array}$ \\
\hline Onsite dry storage & $\$ 161,000$ & $\begin{array}{l}\$ 120,000 \\
\min . * *\end{array}$ & $\$ 281,000$ & $\begin{array}{l}\$ 134,000 \\
\text { min. }\end{array}$ \\
\hline Total disposal of sources & $\begin{array}{l}\$ 212,000 \\
\text { min. }\end{array}$ & $\$ 120,000$ & $\begin{array}{l}\$ 332,000 \\
\text { min. }\end{array}$ & -- \\
\hline
\end{tabular}

- These costs include BNL costs (for oversight and the clean up of the physical facility itself). Estimates are based on FY99 costs adjusted for an annual fiscal inflation factor of 5\%.

** These costs do not include onsite dry storage costs, not available at this time.

Consideration of the options and cost estimates reveals that neither of the options involving partial disposal of sources is viable, particularly the one involving removal of only some of the sources from the GIF. This is because preparation for and conducting a source removal operation is a significant cost in itself, representing about half of the cost for total removal. Removal of all sources from the GIF and placing in dry storage onsite appears to be a less expensive option, but the cost for monitoring and maintaining this inventory are not available. Thus, the actual costs of this option will be much larger. By comparison, continued operation of the GIF represents the least expensive option for FY99 and defers the source removal expense to FY03, the projected end of the useful life of the current sources.

From an economic and safety viewpoint alone, the choice of preferred option lies between recycling or total disposal of all sources during FY99. This will be resolved by preparing a bid package that addresses both options. The final cost estimate to result from this is expected to be in the range $\$ 150,000$ to $\$ 250,000$. In addition, BNL costs will be incurred due to the decommissioning of the physical facility $(\$ 30,000)$ and ancillary activities $(\$ 90,000)$. 


\section{TABLE OF CONTENTS}

Executive Summary $\ldots \ldots \ldots \ldots \ldots \ldots \ldots \ldots \ldots \ldots \ldots \ldots \ldots \ldots \ldots \ldots \ldots \ldots \ldots \ldots$ iii

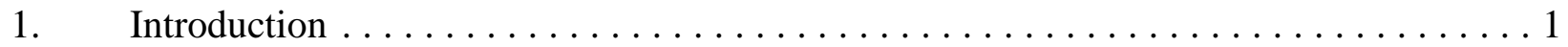

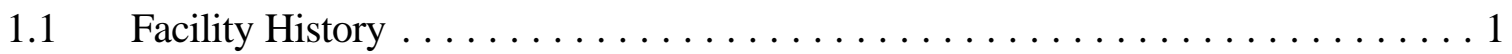

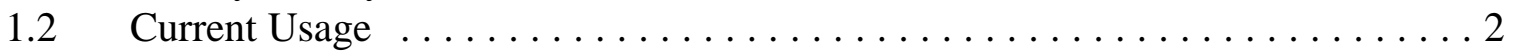

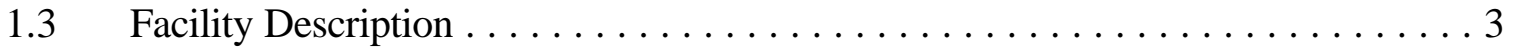

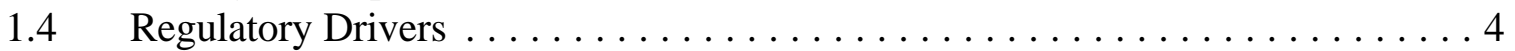

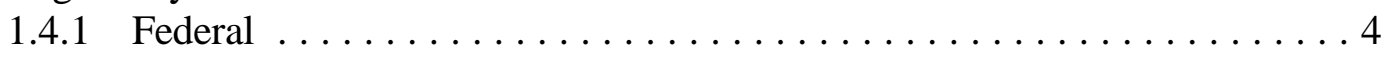

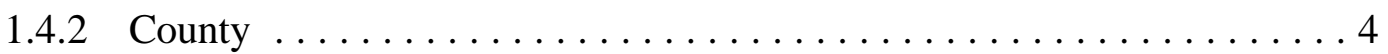

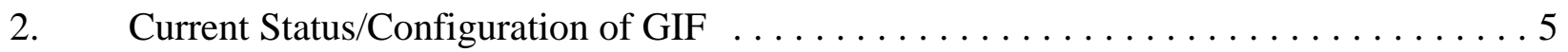

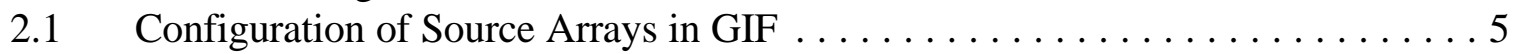

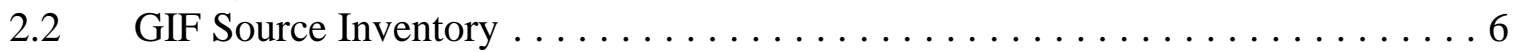

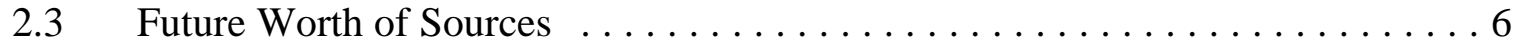

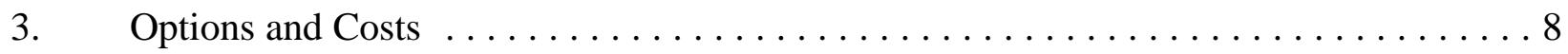

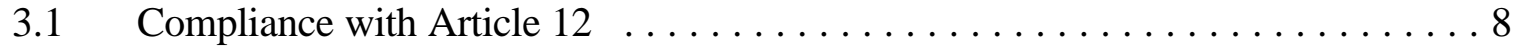

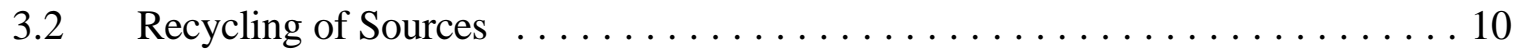

3.3 Partial disposal of sources, with onsite storage or use $\ldots \ldots \ldots \ldots \ldots \ldots$

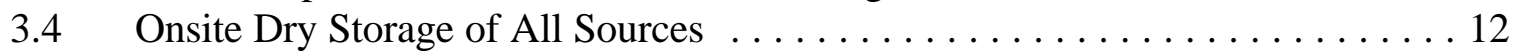

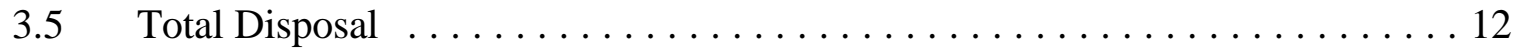

3.6 Physical Facility Decommissioning Costs $\ldots \ldots \ldots \ldots \ldots \ldots \ldots \ldots \ldots \ldots$

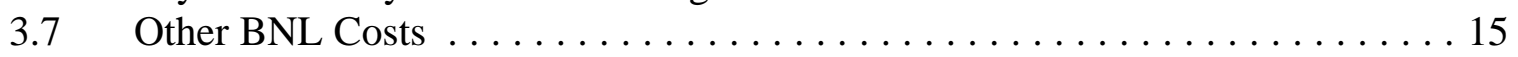

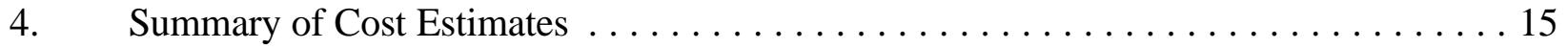

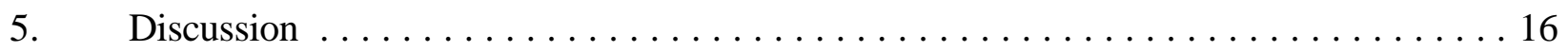

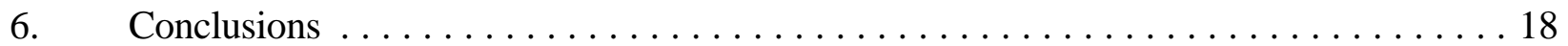

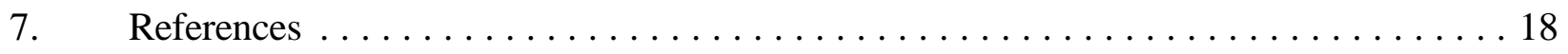

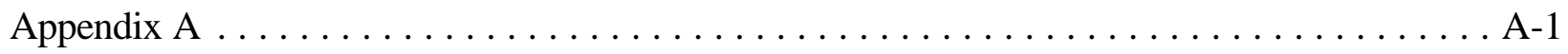

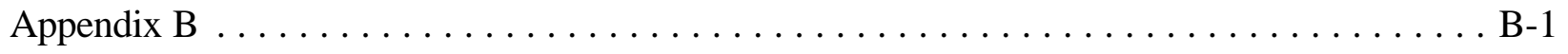




\section{LIST OF FIGURES}

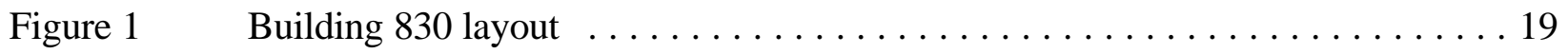

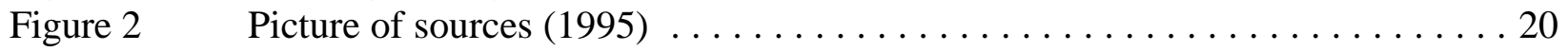

Figure $3 \quad$ Covered pool with all air tubes in place $\ldots \ldots \ldots \ldots \ldots \ldots \ldots \ldots \ldots \ldots \ldots$

Figure $4 \quad$ Pool with four air tubes in place and new cover $\ldots \ldots \ldots \ldots \ldots \ldots \ldots \ldots \ldots \ldots$

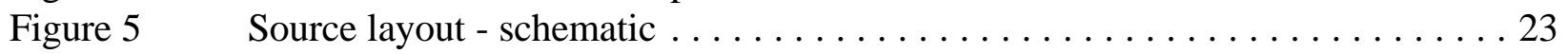

Figure $6 \quad$ View of sources with tubes removed. $\ldots \ldots \ldots \ldots \ldots \ldots \ldots \ldots \ldots \ldots \ldots$

\section{LIST OF TABLES}

Table $1 \quad$ GIF Water Radioactive and Chemical Constituents $\ldots \ldots \ldots \ldots \ldots \ldots$

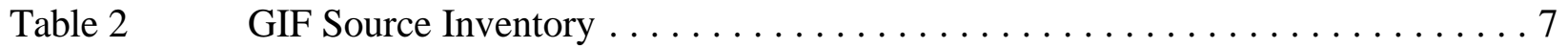

Table 3 Estimated Water Treatment System Costs . . . . . . . . . . . . . 9

Table 4 Estimate for Packaging, Transport and Disposal: Chem-Nuclear Systems, Inc. . 14

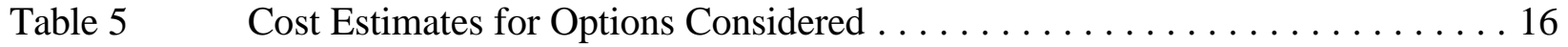




\section{Building 830 Gamma Irradiation Facility \\ Evaluation of Options for \\ Its Future Disposition}

\section{Introduction}

In the spring of 1997, the Suffolk County Department of Health Services audited the BNL site, and identified the Building 830 Gamma Irradiation Facility (GIF) as an underground tank regulated under Suffolk County Health Code, Article 12. As a result of this audit, a project was initiated to review the GIF and to collect information to develop an options list for its future disposition.

The overall objective of this task was to evaluate the decontamination and decommissioning (D\&D) of the GIF, including the proper disposal of the cobalt-60 sources currently located in the GIF. This objective was accomplished through the performance of the following subtasks.

1. Characterize the GIF and the cobalt-60 sources

a) Compile available data on the physical and radiological characteristics of the gamma sources.

b) Conduct underwater surveys to verify visually the physical state of the sources, and if possible, their activity levels (curie content).

c) Prepare the pool, to the extent possible, for removal of the sources.

2. Identify options for future disposition

a) Contact other gamma facilities and find out their experiences with recycling, disposal, and D\&D.

b) Contact vendors for the disposal or recycling of the cobalt-60 sources. Identify options and factors affecting them, such as costs, regulatory issues, health and safety requirements, equipment availability.

This report summarizes the results of these subtasks. The remainder of this introductory section gives a description of the GIF, provides a brief history of the facility, and discusses the applicable Article 12 requirements. Section 2 focuses on the sources themselves, and the current facility configuration. Contacts with other gamma facilities are summarized in Section 3 . Section 4 presents the options developed from these contacts and from BNL experience, and their estimated costs. Costs are tabulated and compared in Section 5, and Section 6 presents conclusions.

\section{$1.1 \quad$ Facility History}

The GIF was added on Building 830 (then called the High Intensity Radiation Development Laboratory, or HIRDL) in 1967 to provide a place for lower-intensity irradiation experiments. Another motive for constructing the GIF was to reduce crowding at the HIRDL transfer canal, 
located between the Hot Cells in Building 830, which was the site of many irradiation experiments at the time. The primary mission of HIRDL was to fabricate cobalt-60 sources for use at BNL and for shipment to sites world-wide under the Atoms for Peace program of the 1950's and 1960's. (Some cesium-137 sources were handled in the fabrication of portable irradiators as well.) A second HIRDL mission was irradiation studies, including the irradiation of large quantities of food. These programs, carried out by the Radiation Division of the Department of Nuclear Engineering at BNL, were terminated in 1973. Subsequently, many of the sources at the HIRDL (but not the GIF) were shipped for disposal. Those that were not shipped were placed in the GIF for use or storage.

Following the program changes in 1973, the GIF continued to be used as an irradiation facility for assorted programs. Two notable features of the period from 1973 to the present are that (1) the facility was operated by the organization occupying Building 830, and (2) there was no formal program with DOE to support its operation. The organizations operating the facility usually made the greatest use of it until the 1990's. Various other users in BNL and off-site, made use of the facility, often for low or nominal fees. Irradiations were for different types of investigations, such as determining radiation effects on materials, sterilizing samples, and qualifying materials for radiation environments.

\subsection{Current Usage}

The GIF is now used regularly to irradiate piezoelectric cells for a "Work-for Others" customer, GEC-Marconi, as a manufacturing step in the preparation of an advanced piezoelectric material. This has brought in approximately $\$ 20,000$ to $\$ 30,000$ per year over the last five years, and in the last fiscal year, about $\$ 50,000$. The company has expressed an interest in continued irradiations in FY 1999 amounting to at least \$20,000. It is primarily because of this company's interest that several tubes were left behind in the GIF during the tube removal operations.

Earlier this year, an additional marketing area was identified when two small New York companies expressed an interest in using the GIF to qualify electronic components for space service according to NASA requirements. These companies balked at the current full cost recovery price charged to non-BNL and non-DOE entities (about \$3200 per irradiation in FY98). Since the time that these inquiries occurred, one potential avenue for providing support to such small company efforts was identified in the Office of Technology Transfer. Some funds are available in increments of $\$ 5,000$. Total potential income from this source might amount to $\$ 10,000$ to $\$ 15,000$ per year.

Additional outside sources for potential research are also being pursued, e.g. to investigate the feasibility of using gamma irradiation to eliminate biological infestations in museum pieces. These attempts to obtain other sources of funding have not been successful, to date.

The GIF is a unique facility in providing a uniform dose rate in a relatively large sample volume. The facility design is such that it continues to present a relatively low hazard to the environment, and the highest activity sources still in the inventory will provide useful radiation dose rates for 5 to 8 more years. Full consideration of the uniqueness of the GIF against the cost of 
complete decommissioning should be made in the evaluation of whether to keep the strongest sources at BNL for further use.

\subsection{Facility Description}

The GIF is located at the northeast corner of Building 830, in an addition to the original building (see Fig. 1). The addition (sometimes called 830A) includes a small machine shop separated from the GIF by a ten-foot dividing wall. The GIF consists of a pool, $8 \mathrm{ft}$. by $10 \mathrm{ft}$. and $13 \mathrm{ft}$. deep, with sealed cobalt- 60 gamma sources. The water depth provides shielding from the cobalt- 60 gamma sources located at the bottom of the pool. The pool liner is a stainless steel tank, $3 / 8 \mathrm{in}$. thickness at the sides and $1 / 2 \mathrm{in}$. thick at the bottom. Water from the pool is circulated through a chiller/filter system, maintaining pool temperature at $7^{\circ} \mathrm{C}$ to minimize algae growth. The filter system contains two fiber filters in the recirculation system. Ion exchange beds are also installed in the chiller/filter system, but have been valved off for at least 15 years.

The cobalt-60 is in the form of "pencil," "tabs," or "flat" sources encapsulated in stainless steel tubes or sleeves. The tubes are held in arrays in stainless steel source racks at the bottom of the pool in an upright, cylindrical orientation, arranged around the circumference parallel to the axis. The tubes in the racks form a cylinder about 6 in. diameter and 12 in. high. Most of the source arrays are inside open-topped lead casks (see Fig. 2). The purpose of the casks was to provide shielding to prevent the arrays from interacting. Thus, dose rates at one source array were essentially entirely due to the cobalt- 60 contained in the array.

There are 23 source arrays; the weakest sources contain less than 10 curies, the strongest (Tube 8) has about 5,000 curies. The dose rates for the sources (at the bottom of the air tubes) range from kilorads per hour to megarads per hour.

Stainless steel air tubes $16 \mathrm{ft}$ x 4 in. OD x 16 gauge wall thickness are inserted vertically into the centers of the source arrays and rest on the bottom of the pool. One inch lead jackets around the air tubes above the water level counter weigh the tube buoyancy, as well as provide shielding to personnel.

Safety features focus primarily on maintaining the water level shielding the sources. An area radiation monitor is set to alarm through the entire building if radiation levels exceed $5 \mathrm{mrem} / \mathrm{hr}$, a situation which can occur if water levels drop more than 5 feet. A refill system activated by a float is available if water is lost from the tank. (The refill system is designed to activate when water level drops 6 inches.) There is a water meter on the refill line (readings are recorded weekly) to monitor when the refill system activates. The refill system has a secondary shut-off activated by a float to prevent tank overflow.

The facility configuration has undergone limited changes over the years. In 1973, multiple source arrays (and air access tubes) were placed in the GIF from the HIRDL facility for storage and for use. In 1977, one source array was removed to Building 526. This array was later transferred to Hazardous Waste Management (HWM). 


\subsection{Regulatory Drivers}

\subsubsection{Federal}

Due to its design and passive safety features, the facility has for the most part had low maintenance/operating costs. However, in 1992-3, new standards promulgated by DOE changed this. Under DOE STD-1027-92, the GIF was classified as a Category 3 (non-reactor) Nuclear Facility, because its inventory exceeded 280 curies. (The Category 2 lower limit is 190,000 curies.) A Category 3 facility requires a higher level of safety and operations documentation than was previously maintained for the GIF. A Safety Analysis Report (SAR), a Quality Assurance Plan (QAP), a Training Program, a Maintenance Implementation Plan, and a Conduct of Operations conformance plan were required. The documentation addressing these requirements was prepared, and the SAR and QAP were approved by DOE. However, in conjunction with the Biology and Medical Departments, who also have low-hazard irradiation facilities, an exemption was applied for and obtained from DOE. Thus the GIF is now classified as a radiological facility and is exempt from other Category 3 requirements.

As a result of the safety reviews for the Category 3 document upgrade, a water meter and overflow protection were added to the water refill system. In addition, the emergency refill line, a 3 -inch plastic pipe extending to the front of Building 830, was replaced with a copper pipe with a connection at the back of the building. A security system of motion detectors, surveillance camera, and door sensors was installed in 1996. Entry to the GIF now requires contacting the BNL Police.

\subsubsection{County}

The prime regulatory driver that prompted this evaluation of the GIF is Suffolk County Health Code, Article 12. Article 12 imposes specific requirements on tanks containing hazardous materials, to minimize the potential for releasing these materials to the environment. Article 12 applies because release of water from the pool constitutes a potential release of hazardous material. The water in the pool contains small amounts of radionuclides and hazardous constituents [1]. These are listed in Table 1 together with the corresponding drinking water standards. The lead present came from the corrosion of lead shielding in contact with water at the tops of the air tubes. The presence of copper derives from water chiller/filter system, which is all copper. Only lead exceeds levels allowed for drinking water and for release to sanitary sewer systems. Other regulated metals have not been detected, except for cadmium, which is below regulated levels. The concentrations of cobalt-60 and cesium-137 are extremely low and well below drinking water standards. 
Table 1

GIF Water Radioactive and Chemical Constituents

\begin{tabular}{|c|c|c|}
\hline Constituent & Concentration & $\begin{array}{c}\text { Drinking Water } \\
\text { Standards* }\end{array}$ \\
\hline cobalt-60 & $14.2 \mathrm{pCi} / \mathrm{L}$ & $100 \mathrm{pCi} / \mathrm{L}$ \\
\hline cesium-137 & $4.6 \mathrm{pCi} / \mathrm{L}$ & $200 \mathrm{pCi} / \mathrm{L}$ \\
\hline lead & $68 \mathrm{ppb}$ & $50 \mathrm{ppb}$ \\
\hline cadmium & $0.5 \mathrm{ppb}$ & $10 \mathrm{ppb}$ \\
\hline copper & $22 \mathrm{ppb}$ & -- \\
\hline
\end{tabular}

* 10CFR Part 141, Sections 141.11 and 141.16

\section{Current Status/Configuration of GIF}

\subsection{Configuration of Source Arrays in GIF}

When this study was begun, it was anticipated that some (if not all) of the sources would be disposed of, and work was undertaken to simplify access to and removal of the sources. Toward this end, 17 air tubes used to access sources for sample irradiations were removed. The four left intact were those used most recently (within the last five years). A view of the covered pool with before tube removal is shown in Fig. 3. A view of the four remaining air tubes, associated with arrays 8, 10, 19, and 20, and a new cover, is shown in Fig. 4.

Visual observation of the tank bottom indicated that there was layer of sediment on the bottom of the pool, particularly at the base of the Tube 21, the aluminum tube installed in 1981 . To remove this sediment, a standard diatomaceous earth pool filter was purchased and used to vacuum the tank bottom (and the walls), as well as to filter solids that were stirred up during vacuuming and obscured the view of the sources. It became apparent that some of the coarser sediment was aluminum oxide, and a finer white-colored component was probably a lead oxide or carbonate from corrosion of the lead shielding in contact with the water at the top of the air tubes. Efforts to remove the sediment are continuing.

A schematic diagram detailing the configuration of source arrays in the GIF is shown in Fig. 5. This is the historical configuration (since the late 70's), and no attempts have been made to change it thus far. The schematic also details which source arrays had air tube access. The source arrays themselves, except for \#19, can be seen residing on the bottom of the pool in Fig. 6. Partial removal of the sediment is also visible. 


\subsection{GIF Source Inventory}

As described in Section 1.3, the GIF consists of 23 arrays of sources, 4 of which are now accessed by air tubes. Historical information on the number and activity of the cobalt-60 sources in the GIF had been assembled earlier [2] and review of those data indicated that information was lacking on the characteristics of a significant number of the individual sources within the arrays. Verification video and radiation probe surveys conducted during the present evaluation were used to update the information and clarify some of the uncertainties [3,4]. Table 2 summarizes the source details as they are currently known.

The actual type of source has been ascertained from the historical records for 308 of the individual sources but is not available for the other 46 sources. The total activity is known with some degree of confidence for 21 of the 23 arrays, but individual source data are available for only 126 of the total of approximately 354 sources. The two arrays where the activity is largely uncertain, S-2 and S-7, contain, respectively, 24 sources and 8 sources, all of unknown type. The activities recorded in Table 2 for these arrays represent estimates derived from comparison of measurements taken with an Eberline RO7 radiation probe.

\subsection{Future Worth of Sources}

As is apparent in Table 2, there exists great variation in the activities of the arrays and individual sources. Arrays 8 and S-1 contain the highest activity sources (average source activity in array 8 is 567 curies, that in array S-1 is 648 curies). These two arrays still have a useful life as irradiation vehicles, producing about $1 \mathrm{Mrad} / \mathrm{h} \mathrm{each}^{* *}$, as indicated in Section 1.2. No other arrays have such a capability in their current configurations. Arrays 19, 20 and S-2 contain a total of 72 sources with average activity of between 100 and 125 curies, and it is conceivable that reconfiguration could produce two arrays each capable of producing $0.5 \mathrm{Mrad} / \mathrm{h}$ or greater. The remainder of the arrays contain 266 sources with average activity of less than 100 curies. These sources have little worth as components of irradiation vehicles though some might enter the recycling market through remelting with sources of very high activity. Some 60 sources have such low activity (less than about 12-13 curies) that they can be considered to have no further use whatsoever.

** A dose rate of $1 \mathrm{Mrad} / \mathrm{h}$ is usually considered a lower minimum for irradiation studies, although lower dose rates, to $100,000 \mathrm{rad} / \mathrm{h}$ are also acceptable. Most irradiation studies focus on effects that occur after a total dose of 1 to $100 \mathrm{Mrad}$ are achieved. In some cases, 1,000 Mrad are desired. The important point is that a viable source array will provide the desired total dose within a reasonable time. 
Table 2

GIF Source Inventory

\begin{tabular}{|c|c|c|c|c|c|}
\hline $\begin{array}{l}\text { Array } \\
\text { No. }\end{array}$ & $\begin{array}{l}\text { Total No. } \\
\text { of Sources }\end{array}$ & $\begin{array}{c}\text { Total curies in Array } \\
(9 / 98)\end{array}$ & $\begin{array}{l}\text { Curies per } \\
\text { Source* }\end{array}$ & $\begin{array}{c}\text { Source } \\
\text { Activity } \\
\text { Documented }\end{array}$ & $\begin{array}{l}\text { Source Type } \\
\text { Documented }\end{array}$ \\
\hline 1 & 24 & 1510 & 63 & 24 & 24 \\
\hline 2 & 24 & 1501 & 63 & 24 & 24 \\
\hline 3 & 20 & 987 & 49 & 20 & 17 \\
\hline 4 & 20 & 989 & 49 & 20 & 16 \\
\hline 6 & 20 & 972 & 48 & 20 & 16 \\
\hline 7 & 12 & 292 & 24 & 12 & 12 \\
\hline 8 & 8 & 4536 & 567 & 0 & 8 \\
\hline 10 & 6 & 65 & 11 & 0 & 6 \\
\hline 11 & 6 & 63 & 11 & 6 & 6 \\
\hline 12 & 16 & 34 & 2 & 0 & 16 \\
\hline 13 & 8 & 16 & 2 & 0 & 8 \\
\hline 14 & 4 & 6 & 2 & 0 & 4 \\
\hline 15 & 4 & 5 & 1 & 0 & 4 \\
\hline 16 & 8 & 13 & 2 & 0 & 8 \\
\hline 19 & 24 & 2682 & 112 & 0 & 24 \\
\hline 20 & 24 & 2571 & 107 & 0 & 24 \\
\hline S-1 & 8 & 5184 & 648 & 0 & 8 \\
\hline $\mathrm{S}-2$ & 24 & $\sim 3000$ & $\sim 125$ & 0 & 0 \\
\hline S-3 & 24 & 2268 & 95 & 0 & 24 \\
\hline S-4 & 36 & 1781 & 49 & 0 & 36 \\
\hline S-5 & 18 & 891 & 50 & 0 & 18 \\
\hline S-6 & 8 & 292 & 37 & 0 & 0 \\
\hline S-7 & 8 & $\sim 100$ & $\sim 13$ & 0 & 0 \\
\hline Total & 354.00 & $29,767.00$ & $2,130.00$ & 126.00 & 303.00 \\
\hline
\end{tabular}

* - calculated by assuming all sources in an array are of equal activity 


\section{Options and Costs}

Several options are available for deciding on the future of the GIF and its cobalt-60 sources. These range from compliance with Article 12 and subsequent retention of all the sources in the GIF to immediate and complete decommissioning, decontamination, and disposal of all the sources as radioactive waste. The options considered in this evaluation fall into five categories:

! Compliance with article 12, retention of all sources

! Recycle sources, either directly to other facilities or indirectly via commercial enterprises

! Partial disposal, retention of some sources on site

! Onsite dry storage of all sources

! Immediate and complete decommissioning, disposal of all sources.

These options are described in detail in the following subsections. Two additional subsection provides an estimate of the cost of decommissioning the physical facility after the sources have been removed and for other BNL costs.

Also, a survey was made of the decommissioning experience and source requirements at other facilities. The results of the survey are summarized in Appendix A.

\subsection{Compliance with Article 12}

Section 2.3 notes that the GIF still has some value for irradiation purposes. However, for this asset to be exploited over the remaining useful life of the most active sources, the GIF must be brought into compliance with Article 12.

In considering this option, it is assumed that the GIF will continue to operate through to the year 2003, at which point all the sources will have ceased to be of any significant use. Concurrent with this is the need to maintain the GIF and to uprate it as necessary to meet Article 12 requirements. Full decommissioning of the facility and disposal of all sources is deferred to FY03.

In its current configuration, the GIF meets the spirit of Article 12 requirements because administrative and engineering measures assure that a release of pool water to the environment is unlikely, and, should one occur, would be detected. The water level needs to be maintained to shield the sources. Water loss through evaporation is minimized by chilling the water and covering the pool. Should water be lost, through a leak or by evaporation, a refill system operated by a float automatically adds water. A meter on the refill line monitors the quantity of water added to the pool. Meter readings are recorded once a week. In addition, water levels are measured weekly by a gauge mounted on the pool cover. Since readings have been recorded (1995), there has been no indication 
of the water level dropping or of the refill system operating. Release of water by over-filling (because the refill system valve fails to close) is prevented by a second float which operates a mechanical shutoff valve at the outlet of the refill line.

Installation of a water treatment system (or renovation of the existing chiller/filter system to include ion exchange beds) to remove the lead contamination in the water is the simplest and potentially least expensive approach to remove the need for an Article 12 permit. If the pool water is purified and kept that way, through an acceptable monitoring program, then the GIF tank would not be considered a container of hazardous materials that could potentially contaminate the environment by leaking.

Dissolved cobalt-60 and cesium-137 would also be removed by the water treatment system. The low levels still present in the GIF water are most likely residues from when the sources were encapsulated with stainless steel jackets, and used in the HIRDL transfer canal, between the Building 830 Hot Cells. Water in the transfer canal had similar low levels of contamination, when it was removed and disposed of in November, 1997. Failure of the steel jackets encapsulating the sources is possible, but the cobalt is in metallic form and would have to corrode before contaminating the GIF water. Such an occurrence would be detected quickly, since the pool water is tested monthly for radioactive contamination. Thus the simplest and most direct way to address the Article 12 issue is to install a water treatment system. It involves using proven technology and to achieve a specific well-defined end- point. The estimated costs for installing a water treatment system, given in Table 3 , amount to a total of $\$ 20,000$.

Table 3

Estimated Water Treatment System Costs

\begin{tabular}{|c|c|}
\hline Design/engineering/safety reviews & $\$ 7500$ \\
\hline Equipment & $\$ 10,000$ \\
\hline Installation & $\$ 2500$ \\
\hline
\end{tabular}

The costs for total disposal of all sources in FY03 were not obtained. These costs have been estimated at a minimum of $\$ 212,000$ for FY99 (see Table 4). It is assumed that these costs will increase somewhat over the subsequent four years due to inflation and other fiscal changes. If the increase is of the order of $5 \%$ per year, the minimum cost for FY03 would be $\$ 258,000$. This minimum figure is based on disposal at Hanford which does not impose a curie surcharge. Disposal costs at Barnwell, which do carry a curie surcharge, are estimated at the present time to be $\$ 150,000$ greater than those at Hanford. Decay between 1998 and 2003 will reduce this surcharge but probably not sufficiently to bring the Barnwell disposal costs below those for Hanford.

Not addressed here are the expenditures needed to keep the GIF operational through the intermediate years. We estimate these costs to be about $\$ 30,000$ per year. 


\subsection{Recycling of Sources}

This option considers the possibility of recycling the most active sources and disposing of the remainder. Recycling of sources, either directly to other facilities or indirectly via fabricators of gamma irradiators, is an attractive option from the viewpoint that the useful life of the sources is thereby extended. In addition, the sources themselves would be moved offsite and the liability associated with continued ownership abrogated.

As indicated in Appendix A, none of the other GIFs contacted expressed an interest in directly recycling our sources into their facilities. Several commercial concerns were then approached regarding the recycling of used sources in general [5]. These included source producers that might have an interest in directly recycling source material and waste management groups with sealed source disposal experience.

Several vendors expressed interest verbally in obtaining some of the higher activity sources for recycling. One, NPI, was prepared to undertake the whole operation, including both recycling of sources where appropriate and arranging the disposal of other sources. NPI provided a written quotation of $\$ 100,000$ but this was for producing a report evaluating the technically feasible alternatives, source handling at BNL, NPI and the disposal site, and use of NPI's containers for shipping. It specifically excluded the cost of disposal and the cost of shipping container rental from others (see Appendix B). This limits the ability to make an explicit comparison of recycling against disposal costs, particularly as it is difficult to reconcile their estimate with the costs estimates provided for total disposal (Table 4). J.L. Shepherd \& Associates expressed interest in taking the highest activity sources and recycling them but did not respond to a request for a quotation in writing. Of the other companies, SEG has a contract with BNL to dispose of radioactive waste but they do not recycle cobalt-60 sources (they suggested contacting J.L. Shepherd \& Associates). In our case, they would treat them as low-level radioactive waste (LLRW) and package them for burial at Barnwell. Similarly, CNSI can treat the sources for disposal as LLRW but do no recycling.

The actual cost of deploying this option is uncertain. If it is assumed that the $\$ 100,000$ quoted by NPI is equivalent to the first three items in Table 4 (mobilization, onsite activities, liner) then another $\$ 52,000$ should be added for burial at Hanford. Thus the total estimate would be $\$ 152,000$ minimum.

\subsection{Partial disposal of sources, with onsite storage or use}

As discussed in Section 2, some of the sources, those with the highest activities, may continue to be viable for use for 5 or more years. Also a consideration is that these sources, because of their high specific activities and total curie contents, can contribute significantly to disposal costs at the present time, depending on the final disposal site. Retaining these sources for future use, or simply storing them until they have decayed to levels which allow for lower disposal costs, offers an alternative with potential economical benefit. This is because the activity decreases at about $12 \%$ per 
year, while disposal costs generally increase but at a lower rate. However, retention of some of the lowest activity sources offers no such benefit whereas their immediate disposal will certainly reduce the overall risk of the GIF.

For this case, criteria for identifying the specific sources to be retained are detailed in Section 2.3. The sources in arrays 8 and $\mathrm{S}-1$ can certainly be used for irradiations because their current dose rates (with an air tube inserted) are still above $10^{6} \mathrm{rad} / \mathrm{h}$, which is about the minimum useful dose rate. Sources with specific activities in the $100 \mathrm{Ci} / \mathrm{g}$ range and above could be consolidated into new racks capable of holding more sources to achieve close to $10^{6} \mathrm{rad} / \mathrm{h}$. Sources below this level could be stored on-site for further decay or shipped for disposal.

There are two alternatives for on-site storage: dry storage in an acceptable container, or continued storage in the GIF. Removing sources into dry storage is described in Section 3.2.4 and may require the availability of a Category 3 nuclear facility. Leaving the sources in the GIF means that future funding will be needed to remove the sources, as well as for packaging and disposal.

Partial disposal and on-site use (i.e. maintaining the GIF with a reduced inventory) would require expenditures to achieve Article 12 compliance (see Section 3.1).

As with the onsite dry storage option, the disposal costs for the partial disposal options can be extrapolated from the estimates provided for total disposal (Table 4). Both the total and the partial disposal options involve the manufacture of a special liner that can be lowered into the pool using the available 5-ton jib crane. After the liner is loaded with all 350 sources, it would be lifted out of the pool and, in the total disposal option, transferred immediately to a Type B shipping cask. In the partial disposal option, the most active sources would be removed, placed in a separate storage cask, and transfered to the dry storage location. With regard to the remaining sources, the retention of the sources from arrays 8 and S-1 onsite would mean that the curie content of the shipping cask would be below the 21,000 curie limit, above which there is a requirement for a highway-controlled route.

Based on the above, it is estimated that deployment of the partial disposal/onsite dry storage option would cost a minimum of $\$ 212,000$ in FY99 and a minimum of $\$ 88,000$ in FY03. Again, as with the total onsite dry storage option discussed in Section 3.2.4, it should be noted that this would be for disposal at Hanford which does not involve a curie surcharge in the first place. Partial disposal with onsite dry storage of some sources will also result in some undefined costs associated with the storage aspect. Unlike the partial disposal/continued storage in the GIF option, these costs could not be compensated for by income from customers wishing to use the sources for additional irradiation work. Thus, although the initial costs would be lower than those associated with the total disposal option, these will be more than offset by later costs.

Disposing of most of the sources while retaining the most active ones in the GIF will initially add to overall costs because of the need to achieve compliance with Article 12 and to continue to maintain the facility. These additional cost estimates are contained in Section 3.1. However, these costs would probably be offset by income from outside users of the facility. Consequently it is estimated that this option will cost a minimum of \$242,000 in FY99. Final disposal costs for FY03 
are not available at this time. They will include the cost of removing the sources from the pool and placing them in a suitable container, then transportation and disposal. Based on the individual item costs in Table 4, the total could be at least $\$ 90,000$.

\subsection{Onsite Dry Storage of All Sources}

Disposal of sources can carry a premium, an addition to the normal volume charge, based on the curie content of the waste. Thus an incentive exists to retain at least the most active sources until they have decayed to the point at which the curie surcharge has been significantly reduced. Although no such advantage would accrue with regard to the lower activity sources, procedures could be simplified if all the cobalt-60 sources were to be disposed of at the same time. Therefore the option was reviewed of removing all the sources from the GIF and placing them in dry storage at BNL for an extended time.

Removing sources into dry storage at the present time means that one cost, that of removing the sources, will not increase (as most deferred costs do). However, dry storage for the sources may require the availability of a Category 3 nuclear facility; that is, HWM will have to store the sources. This may not be acceptable to HWM, but a precedent exists, in that HWM is storing cobalt-60 sources from the Chemistry Department. The costs of dry storage are not readily quantified but would certainly include maintaining Category 3 status.

The disposal costs for this option can be extrapolated from the estimates provided for total disposal (Table 4). Both the onsite dry storage option and the total disposal option involve the manufacture of a special liner that can be lowered into the pool using the available 5-ton jib crane. After the liner is loaded with all 350 sources, it would be lifted out of the pool. The total disposal option would then involve transferring to a Type B shipping cask, but this action would not take place immediately with the dry storage option.

Based on the above, it is estimated that the onsite dry storage option would cost a minimum of $\$ 160,000$ in FY99 (this is based on the first three items in Table 4). Continued dry storage over the following years will result in some undefined costs. Final disposal costs are difficult to estimate as they will depend on the storage time involved. If it is assumed that these costs will increase by about 5\% per year and that the sources are finally disposed of in FY03, the minimum cost for FY03, based on inflated costs of all but the first three items in Table 4, would be $\$ 62,000$. However, it should be noted that this is for burial at Hanford which does not have a curie surcharge.

\subsection{Total Disposal}

The costs for total disposal of all sources at the present time can be broken into four categories:

- $\quad$ cost of containers for the sources,

- $\quad$ costs associated with packaging the sources in the containers,

- transportation costs, and

- $\quad$ disposal fees. 
Transport and disposal regulations require that Type A containers be used. However, the number of sources that can be placed in one container may be limited according to the size of the container and the activity of the sources. Higher activity sources require more shielding, and, depending on available transport casks and disposal site requirements, there may be limitations on the total curies (and thus number of sources) that may be sent in a single shipment for disposal. In addition, the material shipped may require a highway-controlled route and thus lead to increased total cost.

The costs involved in preparing the sources for shipping will depend to some extent on the number of sources to be moved, and what exactly is done with them. There are about 350 sources, and handling them will require using tools that reach 13 feet to the bottom of the pool. Many will be removed from the racks they are now in and consolidated into transport/disposal containers. Moving the containers into the pool and out of the pool to an area for loading onto trucks is also a consideration. Currently installed equipment, especially the 5-ton jib crane, may not be adequate.

The disposal of all 350 sources from the GIF at one time would involve the greatest expenditure as a result of both disposal and shipping requirements. Specifically, the highest activity sources will need to be shielded adequately for transport and may require a controlled route depending on the availability of appropriate transport casks. Such shipping is done on a fairly routine basis but must be organized ahead of time, and be carefully coordinated with states on the shipping route and with the disposal site.

The disposal site options are essentially two: Hanford and Barnwell. A generic cost comparison (provided by HWM) can be based on unit disposal charges. Barnwell charges about $\$ 300$ per cubic foot, plus remote handling fees. Hanford disposal fees for waste requiring remote handling are $\$ 136$ per $\mathrm{ft}^{3}$; that for "regular" low-level waste $\$ 17$ per $\mathrm{ft}^{3}$. These fees do not reflect the cost of disposal containers and transport, which could negate the apparent price difference.

Two vendors were contacted for approximate estimates for shipment and disposal at the two sites. Chem-Nuclear Systems, Inc., handles Barnwell disposal, and GTS Duratek, which also has casks available that could be used to ship to Hanford. Only CNSI provided a response. The estimates included in that response, including a breakdown of the costs of specific activities, are summarized in Table 4. 
Table 4

Estimate for Packaging, Transport and Disposal: Chem-Nuclear Systems, Inc.

\begin{tabular}{|l|r|r|}
\hline & $\begin{array}{c}\text { Option A - Barnwell } \\
\text { Disposal }\end{array}$ & $\begin{array}{c}\text { Option B - Hanford } \\
\text { Disposal }\end{array}$ \\
\hline Mobilization & $\$ 100,000$ & $\$ 100,000$ \\
\hline On-Site Activities & $\$ 40,000$ & $\$ 40,000$ \\
\hline Liner (per liner) & $\$ 21,000$ & $\$ 21,000$ \\
\hline $\begin{array}{l}\text { Cask Rental } \\
\text { (\$1000/day gate to gate) }\end{array}$ & $\$ 6,000$ & $\$ 16,000$ \\
\hline Cask Shipment (per trip) & $\$ 4,200$ & $\$ 15,500$ \\
\hline Demobilization & $\$ 10,000$ & $\$ 10,000$ \\
\hline Disposal (per liner) & $\$ 160,000$ & $\$ 10,000$ \\
\hline Total & $\$ 341,200$ & $\$ 212,500$ \\
\hline
\end{tabular}

These costs assume controlled route shipping and a single shipment. Cost savings may be realized if the controlled route shipping can be eliminated. [Controlled route shipping involves approval of shipments by all States through which the shipment must pass. That is, the signature of the Governors must be obtained.]. Additional costs associated with this were not itemized separately, but the reduction of costs would probably surpass the costs of two shipments, as a minimum.

If the inventory is divided so that two shipments without a highway-controlled route are made, then liner, cask rental and shipment and costs are doubled, adding $\$ 31,200$ to the total for Barnwell disposal and $\$ 52,500$ for Hanford disposal. If two non-controlled shipments are chosen, there would be a waiting period between shipments, since only one cask is available.

Potential extra costs may be incurred through driver detention. Such costs, of the order of $\$ 35$ per hour, are in addition to normal driving duties (these are included in the cask shipment estimates). They depend on various factors, e.g. on how quickly the shipping cask is unloaded, and thus are unpredictable. Each day of detention will cost $\$ 280$. If the cask is involved, an additional $\$ 1000$ rental fee would be invoked.

It should be noted that the major difference between the costs is that of disposal at Barnwell. This arises from, among other items, the imposition of curie surcharges and volume surcharges, neither of which are levied at Hanford.

\subsection{Physical Facility Decommissioning Costs}

An additional cost consideration involves the disposition of the physical facility itself. This would include the costs associated with the removal and disposal (or treatment and discharge) of the pool water. Following this, the tank walls and floor would have to be cleaned and surveyed, to assure that all residual lead and radioactive contamination is removed. The cost of this series of operations would be comparable to that incurred when the Building 830 transfer canal was decontaminated, 
about $\$ 20,000$. Following decontamination, the tank should be removed from regulation under Article 12. To this end, it could be dismantled and physically taken out, or simply backfilled with sand and covered. Neither of these actions was taken with the transfer canal which was placed in "Temporarily Out of Service" status and left empty. Depending on the option taken, the additional costs incurred in removing the tank from Article 12 regulation should cost about $\$ 30,000$.

\subsection{Other BNL Costs}

The decommissioning of the GIF will involve several ancillary activities whose costs will be generally common to all options. These include preparation of the bid package, review of safety evaluations and analyses, and general program liaison and monitoring. Health Physics will be required to provide coverage of activities, and significant HWM involvment might be needed in the case of onsite storage. It is estimated that the cost of performing these ancillary activities will be about $\$ 90,000$.

\section{Summary of Cost Estimates}

The total cost estimates made for continuing use of the GIF after modifications for compliance with Article 12 and those obtained for the various source disposition options are summarized in Table 5. The estimates are given for FY99 and, where applicable, the year of final disposal of all sources (assumed, for convenience, to be FY03 in all such cases). They do not include the costs for final decommissioning of the physical facility itself. The activities involved in that phase would be common to all options but actual costs would probably increase over time to account for inflation and other changes in the fiscal landscape. For FY99 the costs are not expected to exceed $\$ 30,000$. Additional costs include those incurred in various administrative and monitoring activities and will amount to about $\$ 90,000$. 
Table 5

Cost Estimates for Options Considered

\begin{tabular}{|c|c|c|c|c|}
\hline \multirow[t]{2}{*}{ Option } & \multicolumn{3}{|c|}{ FY99 Costs } & \multirow{2}{*}{$\begin{array}{l}\text { FY03 } \\
\text { Costs* }\end{array}$} \\
\hline & Subcont. & BNL & Total & \\
\hline Compliance with Article 12 & --- & $\$ 20,000$ & $\$ 20,000$ & $\begin{array}{c}\$ 404,000 \\
\text { min. }\end{array}$ \\
\hline Source recycling & $\begin{array}{l}\$ 152,000 \\
\text { min. }\end{array}$ & $\$ 120,000$ & $\begin{array}{l}\$ 272,000 \\
\text { min. }\end{array}$ & --- \\
\hline $\begin{array}{l}\text { Partial disposal with onsite dry } \\
\text { storage }\end{array}$ & $\begin{array}{l}\$ 212,000 \\
\text { min. }\end{array}$ & $\begin{array}{l}\$ 120,000 \\
\text { min.** }\end{array}$ & $\begin{array}{l}\$ 332,000 \\
\text { min. }\end{array}$ & $\begin{array}{l}\$ 134,000 \\
\text { min. }\end{array}$ \\
\hline $\begin{array}{l}\text { Partial disposal with continued } \\
\text { use of GIF }\end{array}$ & $\begin{array}{l}\$ 212,000 \\
\text { min. }\end{array}$ & $\$ 20,000$ & $\begin{array}{l}\$ 242,000 \\
\text { min. }\end{array}$ & $\begin{array}{l}\$ 282,000 \\
\text { min. }\end{array}$ \\
\hline Onsite dry storage & $\$ 161,000$ & $\begin{array}{l}\$ 120,000 \\
\min . * *\end{array}$ & $\$ 281,000$ & $\begin{array}{l}\$ 134,000 \\
\text { min. }\end{array}$ \\
\hline Total disposal of sources & $\begin{array}{c}\$ 212,000 \\
\text { min. }\end{array}$ & $\$ 120,000$ & $\begin{array}{c}\$ 332,000 \\
\text { min. }\end{array}$ & --- \\
\hline
\end{tabular}

* These costs include BNL costs (for oversight and the clean up of the physical facility itself). Estimates are based on FY99 costs adjusted for an annual fiscal inflation factor of 5\%.

** These costs do not include onsite dry storage costs, not available at this time.

\section{Discussion}

The BNL GIF is a unique facility that has seen only limited use in recent years. Its usefulness will decrease as the sources currently in the arrays decay. If a decision is made to leave it intact for the time being, funds will be required to bring the facility within Article 12 compliance (thought to cost about $\$ 30,000$ ) and to maintain it (estimated at about 2 man-days per month). These costs could be offset by income derived from outside concerns. However, unless the cobalt-60 sources are replenished, it will cease to be a viable irradiation vehicle by the end of FY03. Total disposal costs at that time are unknown but will almost certainly be considerably higher than those estimated at the present time (a minimum of $\$ 212,000$ for burial at Hanford).

Another option considered was the possibility of recycling the most active sources and disposing of the remainder. This is attractive from the environmental viewpoint but the limited number of sources that might be recycled greatly reduce the potential benefits that might ensue. An initial estimate indicated that this option would cost about $\$ 152,000$ but there is a degree of uncertainty attached. These uncertainties should be resolved by including the vendor in a bid package. On the positive side, this option would result in a reduction in the liability associated with Hanford 
disposal, by transferring ownership of these highest level sources to another entity. However, liability for the vast majority of the sources would remain with BNL.

Two partial disposal options were considered.

The "partial disposal/onsite dry storage" option involves the removal of all the sources from the pool at the same time and storing until decay has reduced them to such a level that final disposal will be simplified. On paper, this implies a significant reduction in final disposal costs. The reality is more complex. The up-front costs of associated with removing the sources from the pool (estimated at about \$140,000) will remain essentially unchanged. However, funds will be required for the shipping and final disposal of the sources, both at present and in the future. The costs associated with these activities (estimated at around $\$ 72,000$ at the present time) will certainly increase, perhaps significantly, in future years. The costs associated with the dry storage aspects have not been defined but need to be taken into consideration. Thus, also considering that disposal at Hanford does not at present involve a curie surcharge, the potential benefits to be derived from onsite dry storage may not, in all likelihood, be realized.

The second partial disposal option is based on continued use of the GIF after the majority of the sources had been removed (leaving only the two highest activity arrays in place). The costs of removing these sources, shipping and final disposal would be essentially those for disposal of all the sources (present lowest estimate about \$212,000). Additional expenditure (see the Article 12 Compliance option) would be required to bring the facility into compliance with Article 12 and to maintain it. As with the Article 12 Compliance option, these costs could be offset by income from ongoing and future irradiation projects. However, the costs of eventual disposal of the remaining sources must be considered. No estimate was sought for such an activity but it may be disproportionately large for the number of sources involved. This option will inevitably cost more than the Article 12 Compliance option with no obvious additional benefits other an increase in the safety of the GIF arising from removal of most of the sources.

Consideration was given to removing all the sources from the pool at the same time then holding them in dry storage onsite to allow further decay prior to shipping for disposal. The attraction of this option is that, by allowing decay, the curie surcharge on disposals can be greatly reduced. In reality, the lowest cost disposal available is at Hanford which does not impose a curie surcharge. Thus any potential benefits are negated and costs will be higher than if all sources were disposed of at Hanford at the present time.

Disposal of all sources from the GIF at the present time is estimated to cost a minimum of about $\$ 212,000$. This includes removal of all sources from the pool, packaging, a single shipment, and disposal at the Hanford site. If two shipments are needed, the cost will increase to about $\$ 265,000$.

Other costs considered were those associated with completing the decommissioning of the physical facility, and with numerous administrative and support functions. The former are not expected to exceed $\$ 30,000$, the latter should not require more than $\$ 90,000$. 


\section{Conclusions}

From the above, it is concluded that neither of the options involving partial disposal of the cobalt-60 sources offers any tangible economic advantage when compared with the costs associated with total disposal. Partial disposal with continued use of the GIF appears to be the most expensive solution. Partial disposal with onsite dry storage will require less expenditure than total disposal in FY99 but funding will be required in future years that will probably offset the savings in FY99. The potential savings to be gained from onsite dry storage are negated by the fact that the present lowest disposal rates, at Hanford, do not include a curie surcharge. The recycling option costs appear to be slightly lower than those of total disposal, but there are uncertainties associated with the former. By comparison, continued operation of the GIF will require considerably fewer funds in FY99 but probably more than the present estimated total disposal costs when the useful life of the current sources is expended, around FY03. Although it is probable that income from outside customers will offset operating costs in the intervening years, it is difficult to see the GIF as a significant profit center without an extension of its capabilities and a concurrent demand for more irradiation space. Thus, from an economic and safety viewpoint alone, the choice of preferred option lies between using the services of a recycling vendor and total disposal of all sources during FY99. This will be resolved by preparing a bid package that addresses both options. The final cost estimate to result from this is expected to be in the range $\$ 150,000$ to $\$ 250,000$. In addition, BNL costs will be incurred due to the decommissioning of the physical facility $(\$ 30,000)$ and ancillary activities $(\$ 90,000)$.

\section{References}

1. Memorandum, "Calculations for GIF Water Treatment System Design," Biays Bowerman, to John Heiser, Mel Cowgill, dated September 18, 1998.

2. Memorandum, "Gamma Irradiation Facility Sources: Inventory and Description," Biays Bowerman, dated November 20, 1995.

3. Memorandum, "Revised Information on Sources in the GIF," Mel Cowgill to Biays Bowerman, John Heiser, dated April 29, 1998.

4. Memorandum, "Underwater Survey of GIF Sources," Biays Bowerman, Mel Cowgill to John Heiser, dated September 18, 1998.

5. Memorandum, "Building 830 Gamma Irradiation Facility D\&D Status Report," Biays Bowerman, John Heiser, Mel Cowgill, to Paul Moskowitz, dated June 16, 1998. 


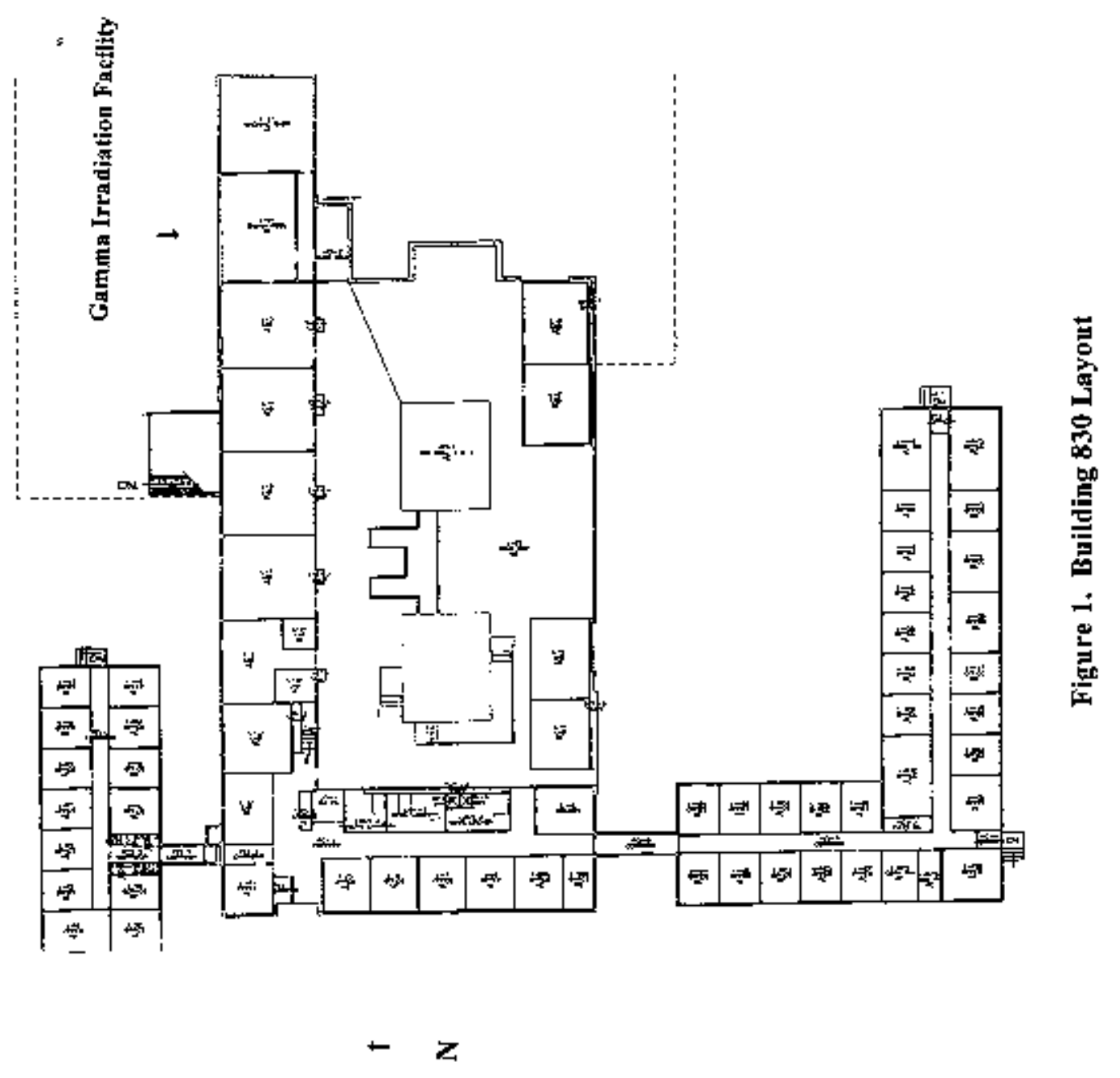




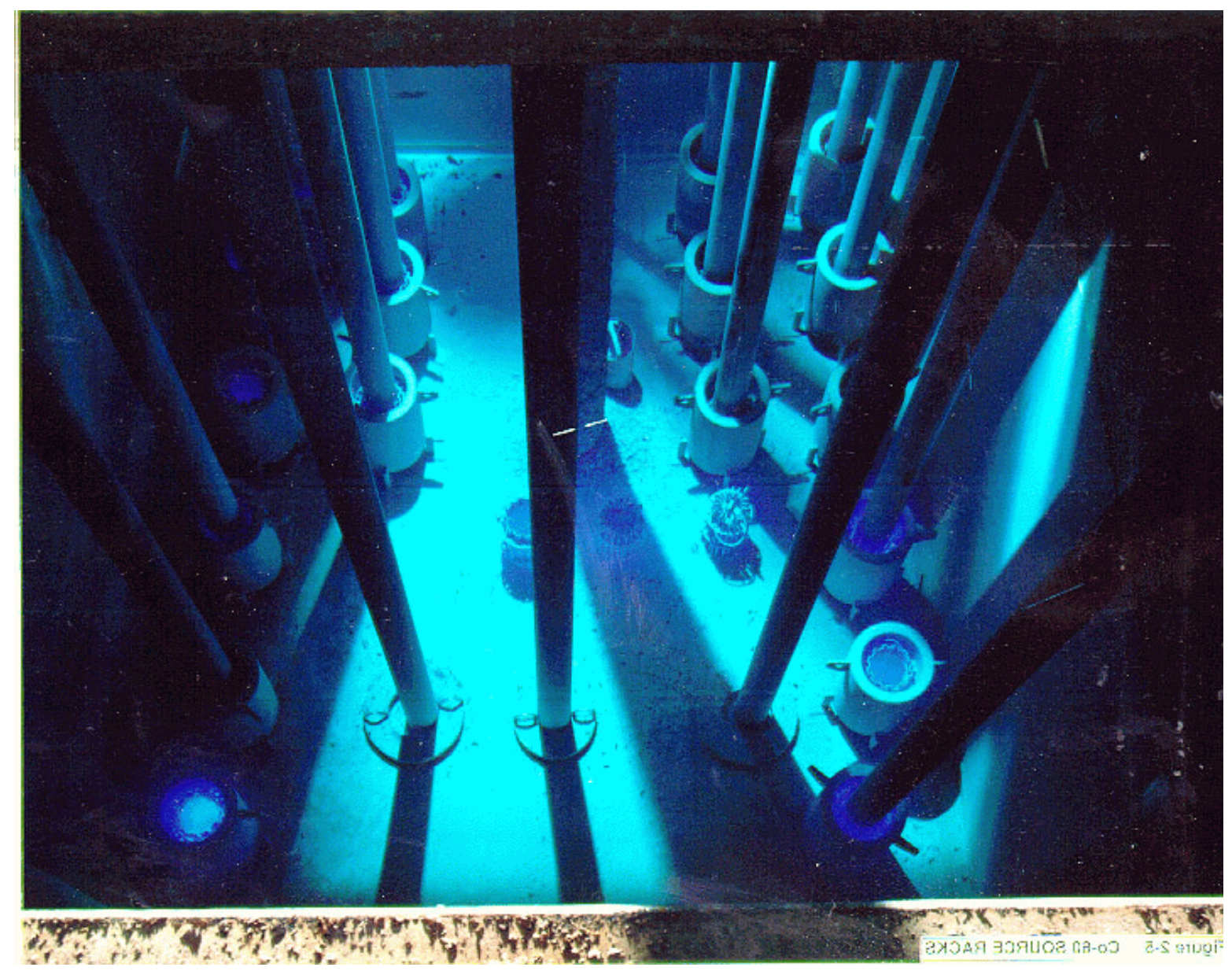

Figure 2 Picture of sources (1995). 


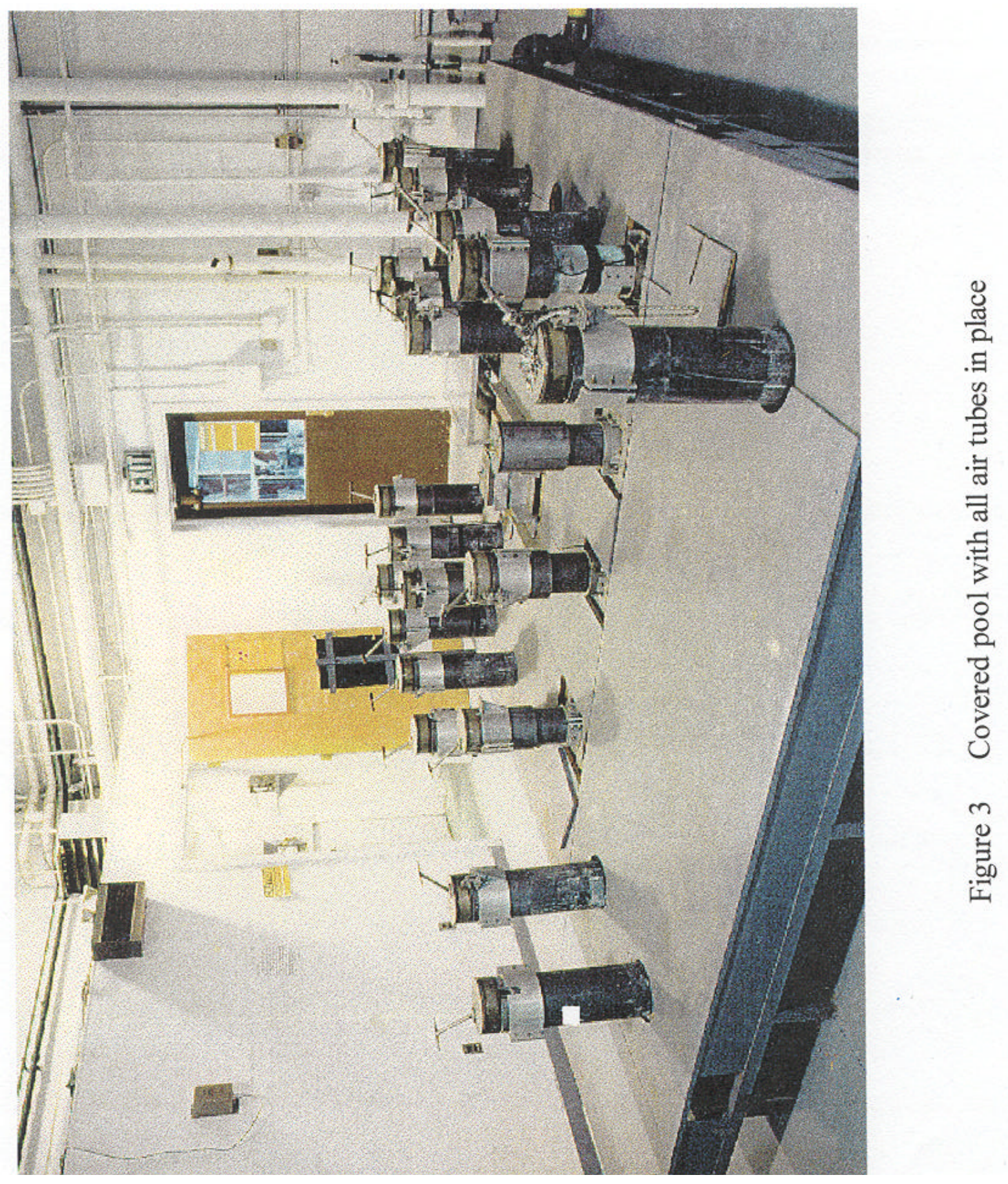




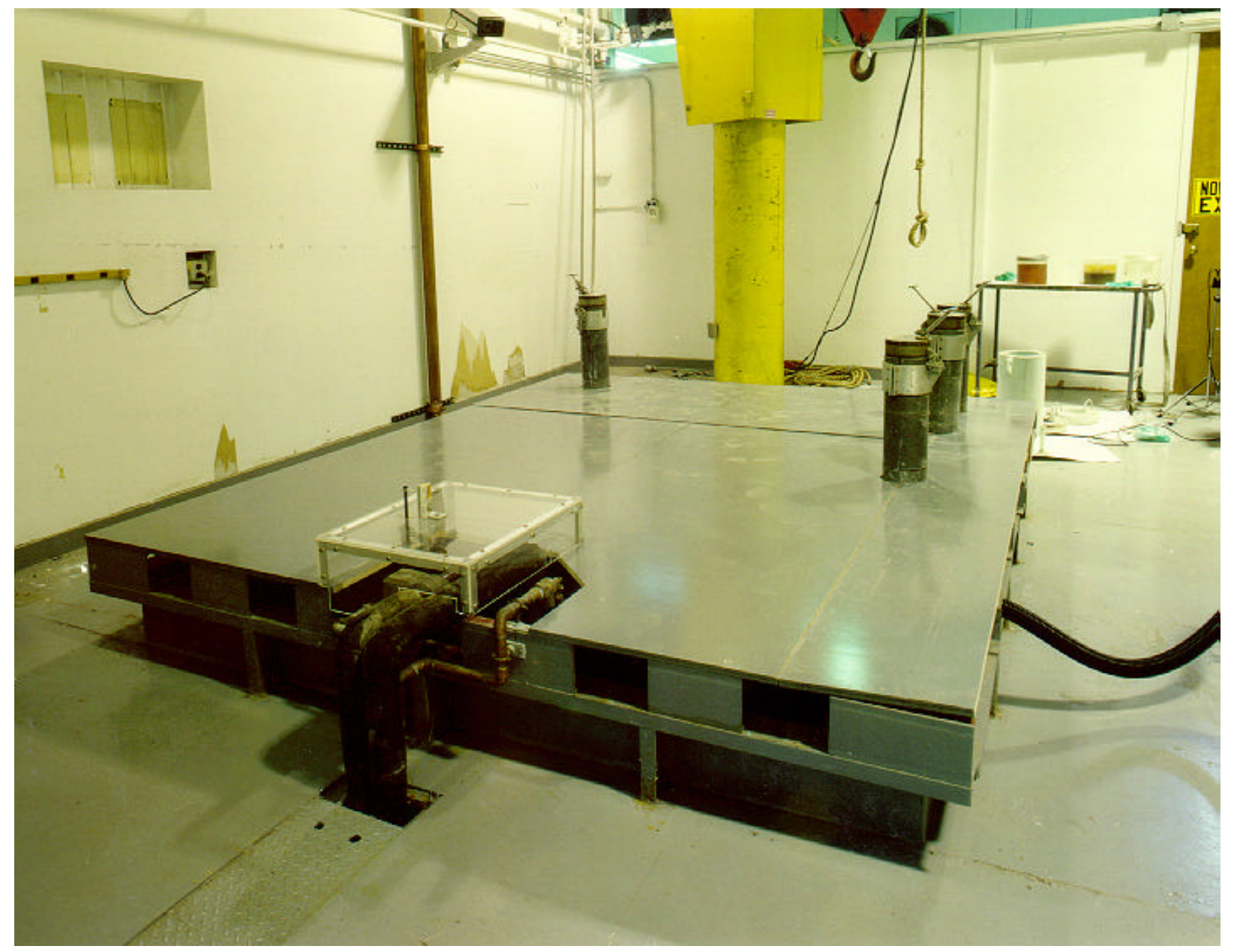

Figure 4 Pool with four air tubes in place and new cover. 


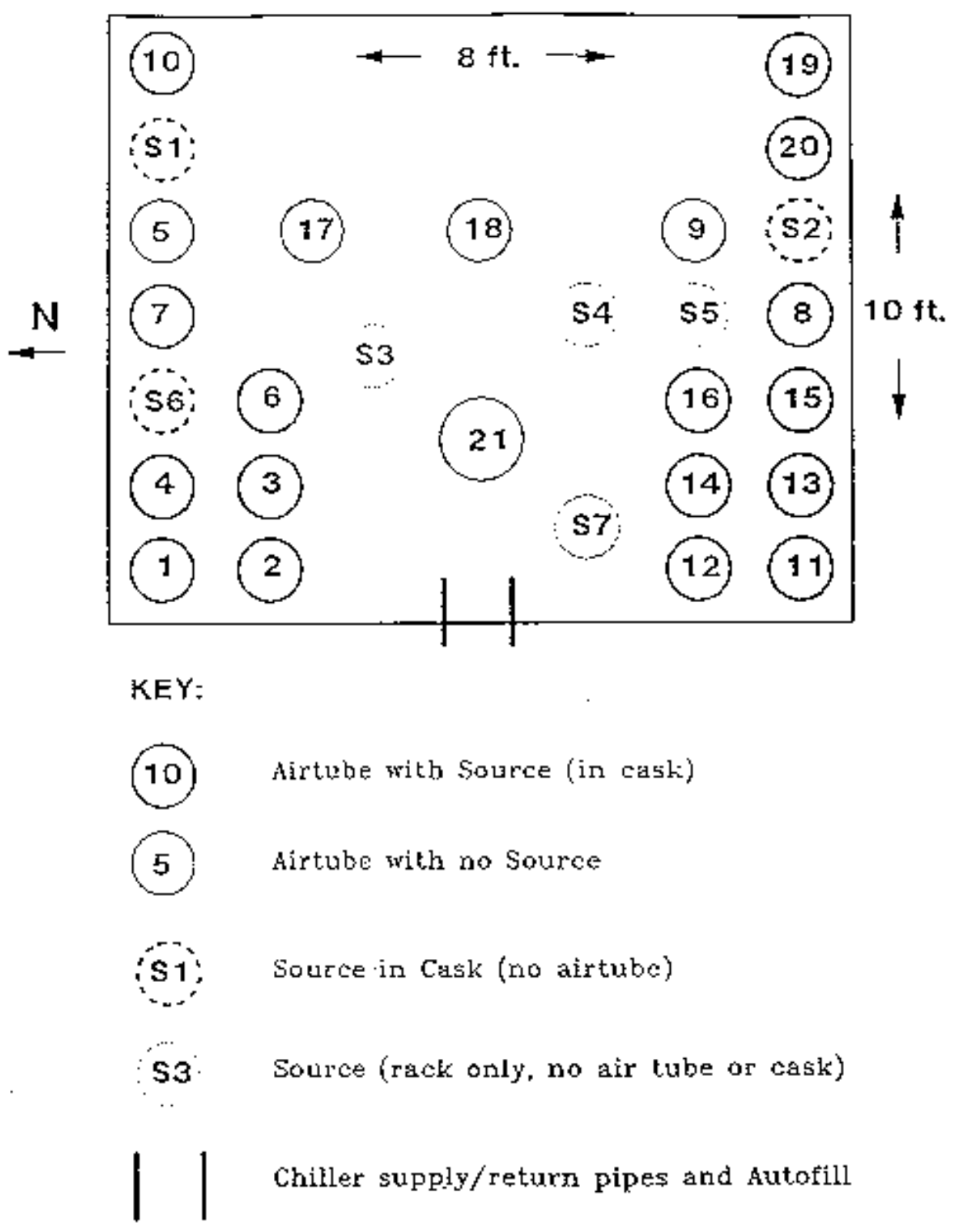

Figure 5 Source layout-schematic 


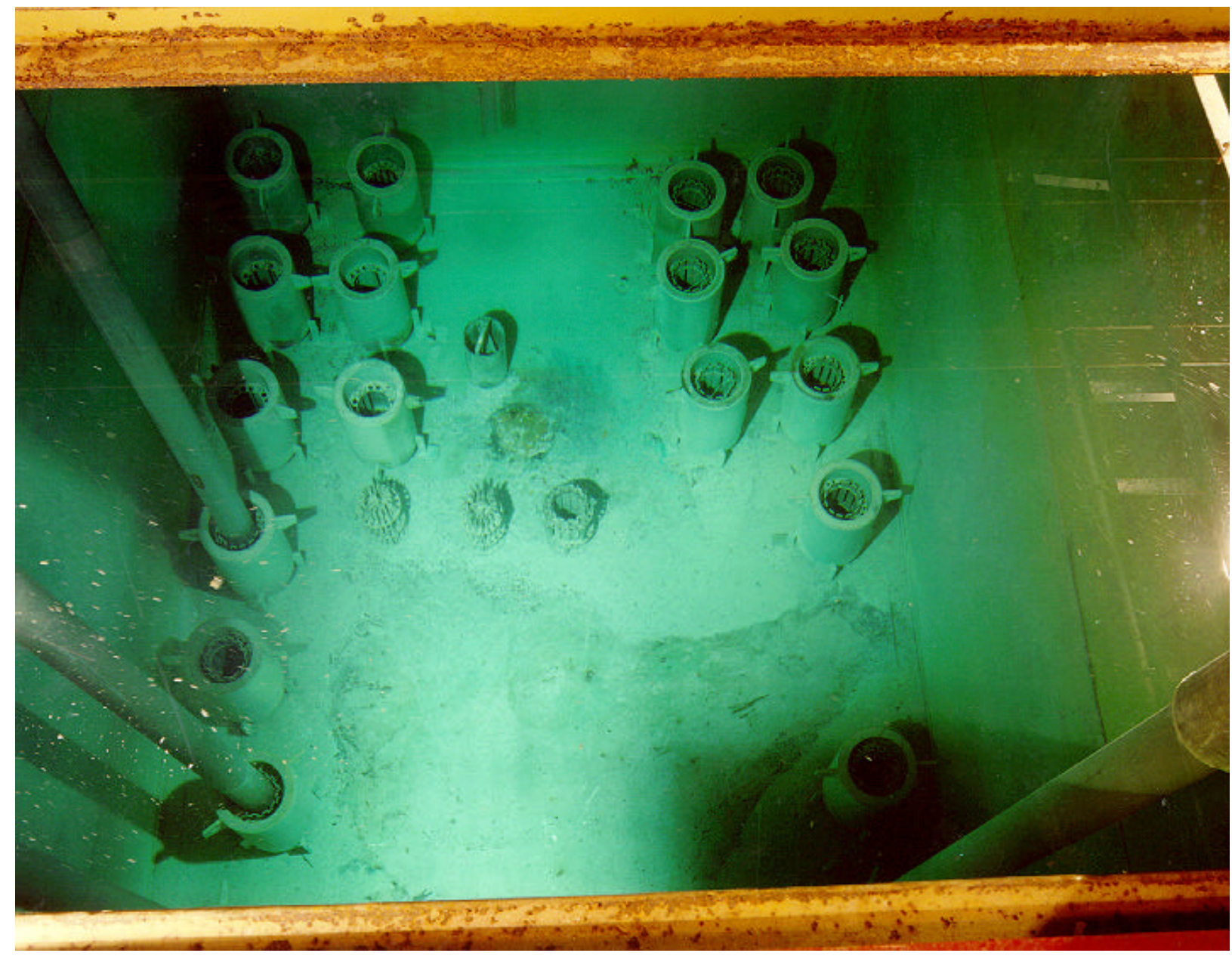

Figure 6 View of sources with tubes removed. 


\section{APPENDIX A \\ Decommissioning and Source Requirements at Other Facilities}

The BNL GIF is one of many such facilities in existence, both in the US and elsewhere. In an effort to take advantage of any prior experience, the operators of ten of these other facilities were contacted to determine if they had experience in the decommissioning of such facilities and in the subsequent disposal/recycling of cobalt sources. They were also asked if they were interested in the recycle of the BNL sources into their facilities [5]. The ten facilities comprised:

Armed Forces Radiobiology Research Institute

Cornell University (Ward Center for Nuclear Sciences)

Georgia Institute of Technology (Neely Nuclear Research Center)

Idaho National Engineering and Environmental Laboratory (Nuclear Reactor Technologies

Department)

Pacific Northwest National Laboratories

Paul Scherrer Institute (Switzerland)

Sandia National Laboratories (Reactor Engineering Technology Center)

University of Cincinnati (Nuclear and Radiological Engineering Department)

University of Michigan (Phoenix Memorial Laboratory)

University of Texas at Austin (Nuclear Engineering Teaching Laboratory)

None of the operators contacted at the above facilities had any experience with decommissioning a GIF nor did any express an interest in recycling our sources. Three noted that servicing of the sources (removal of old ones, replacement with new ones) had been handled by a commercial concern, Neutron Products, Inc. 


\section{APPENDIX B}

Response from Neutron Products, Inc. 


\title{
חEUTRON PRODUCTS inc
}

\author{
22301 Mh Ephraim Rosd, P. O. Bex 68 \\ Dickrson, Maryland 20842 USA \\ 30I-349-500I FAX: 30I-349.2433
}

Septenicax 19, 1998

Erookhaven National Iaboratory ["EML"]

Brookhaven science Associates

Environterstal and Waste Technology center

P. 0 . Box 5000

Upton, Nêt York 11973-5000

VIA FAX: $516-344-4486$

Atta: Biays Bowerman

*el Congill

John Heiser

Paul Hoscowitz

Gentlemen:

I aro writirg parsuant to your Letter of May 28,2998 with attachments, iाy visic to ENL in JulY, and your E-weil mesenge with regard to the willingness abd ability of Neburon Products ("Neutron") to assist gु, in defining ard electing among its alternatives for disposing of (and/or contiuing to use) the largely dex:ayed cobeilt-E0 sources in its Garna Irradiatich Facility (the "GIF").

\section{Bxief Skmmary of Eks's objectives and Alternatives}

About thirty years ago, BAL bailt and feuled the GIF shich, at the time was one of the world's leading facilities for conducting research on many matters including the use of cohalt-60 for radiation processing purfoses. It was equiped at the time with sources containing abort 375 , onot couries; but as the use of radiation processing bectrie conmercialized, the GIP capability becane less ard less w:ique, and the governinent's need and desire to seport radiation research twindlea.

At this point in time, Gig has an estimated 354 dousle encapsulated sources contairing an estimated 31,000 Gries, much of which is of little or no valie, some of which is of negative value. Based upon our analysis of the GIF i:uentory:

The 80 scurces believed to be in Arrays $\# 7,10$ through 16, 3-6 and S-7 contain a total of about 800 curies of cohalt-60, and showld probabily be disposed of with minimul, if any, wontinthed use.

Conversely, the 16 sources believed to reside in Arrays estimated Dy ent to contain about 10,000 curies of cobalt-60 in toto; and may have erough value to warrant continued use on the merits, either at BAE or sone other site. 
Hr. Boweruan et al

Septewber 19, 1998

Page 2

Betwen these extrenes, the 258 soltces believed to reside in Arrays 1 through $6,19,20$, and 3-2 through s-5 are estimated to contain about 18,000 curies of very low specific activity cobalt-60.

Whether it is preferrable to dispoes of all or part of said sources at this time, or extend the useful life of the more active eources in solve way depends upon the cost and risk of each alternative.

It is our uxderstanding that ENL desires above all else to optimize its posts of disposel and its risks of either disposeal or continued use. We believe that, because of its diversified physical rescurces and experienco, Neutron is miquely well chalified to quantify the siltematives; to essist Bit in deciding upon the Irost prudent oxures of action; and to implement whatever decision is reached at mivinrm cost and risk, and maximus benefit.

\section{keutron's oualifiegtions}

For more than three decades, Neutron has engrged in the produstion of coldalt-60 as a br-protuct of mrlear power plant operation; the fabrication, sale, shipping, mathagent, recrcle and disposal of cobelt-60 eources; and the development and commercialization of cobalt-60 applications in radiation processing and radiation oncology. During the period, it bas successfully fabricated, sold and delivered, or used withort adverse incident in its own radiation processing plants, wore than 5,000 scuros containing nearly 50 raillion curies of cobalt-60, about nine million of which have been recycled.

It has shipping containers, source handling tools and techmology, and source encapsulation facilities, tools and texhnology that can be applied to reduce both the ext and risk of hhatever level of disposal and/or use is optimur; and it has prior experience in the field encepsulation and shippent of cobalt-60 sources of chestianable integrity. It also has experienced drivers who are also radiation texhriciars, whereby it has undertaken billions of crrie-miles of highway route control transportation of irxediated targets, rew colalt -60 scurces, spent sources, and recycled cobalt-60 sources.

\section{Netrtiron's Proposal}

Neutron believes that it can evaluate the feasible alternatives; assist ENL in deciding lpon the most prodent course of action; and implement ERL's dexision vis-a-vis continued use or disposal, for a total cost to ENL comprising:

PNL's cost of whatever level of rafioactive naterial disposal is deamed to optintumi

ERL's cost of shipping ocntainer rental from others, plus $\$ 2,50$ per mile of whatever radioactive material transportation is reguired; plus

$\$ 100,000$ for Neutron's work of evaluating alternatives and implementating the choice, incluxing: 
Mr. Botwertiath et al

September 19, 1998

Page 3

a written report of Nebtion's economic evalutation of technically feasible alternatives;

source handling at ENL, Neutron and the disposal site(s); and

the prudent and optirum we of Feutron's source ontainers for stipping.

If requited, after notice timely given, and for a fixed price (if any) to be negotiated in view of the facts that are knows at the tins, there may be arditional charges for the field encapsulation of fajled HNL sources, the reencapsulation of exurces at Dickerson as recessary and desirable for either disposal or contiled use, or the off-optiman ant excessive use of Neutron's shipping containers.

Eorr will proviade, at ro charge to keutron:

Halth phrsics support of all cperations conducted at Bu, and whatever site specific training of Neutron enplopees is required; and

the participation of whatever gerc personnel interact in the evaluation report and the conchuct of the work performed at Bul.

\section{Teris of Papwent}

of the $\$ 100$, 000 fixed price:

$\$ 30,000$ shall be due and payable vithin 30 daps after completion of the evaluation report; and

the balance shall be paid monthly, on a promrata basis, as the implementation of the work is performed.

Shipping and encapsulation, if any, shall be paid after certified completion of the work, and within seven daps after receipt of invoice.

The evaluation of arternatives is to completed by Decenber 31,1999 . The implementation is to be coluleted as scon thereafter as is practical in the cirucjistances that are known to exist at the time; and in substantial confortrance with the schepdule of performance presented in the Evaluation Report.

I believe that the foregoing is responsive to our discussions, and if you concri, please issue an apropriate authorization to proceed. otherwige, feel free to treat this letter as a traft.

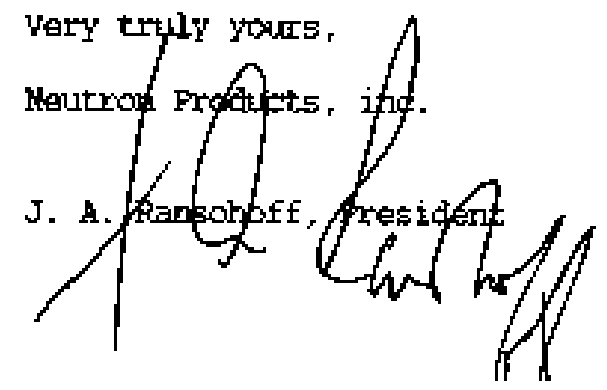

